Article

\title{
Designing a Mesoporous Zeolite Catalyst for Products Optimizing in n-Decane Hydrocraking
}

\author{
Li Tan ${ }^{1,2, *(D)}$, Xiaoyu Guo ${ }^{2}$, Xinhua Gao ${ }^{2,3}$ and Noritatsu Tsubaki ${ }^{2, *}$
}

1 Institute of Molecular Catalysis and Operando Characterization, College of Chemistry, Fuzhou University, Fuzhou 350108, China

2 Department of Applied Chemistry, University of Toyama, Toyama 930-8555, Japan; guoxiaoyuaaa@163.com (X.G.); gxh@nxu.edu.cn (X.G.)

3 State Key Laboratory of High-Efficiency Utilization of Coal and Green Chemical Engineering, College of Chemistry and Chemical Engineering, Ningxia University, Yinchuan 750021, China

* Correspondence: tan@fzu.edu.cn (L.T.); tsubaki@eng.u-toyama.ac.jp (N.T.); Tel.: +81-076-445-6848 (N.T.)

Received: 11 August 2019; Accepted: 8 September 2019; Published: 12 September 2019

check for updates

\begin{abstract}
Mesoporous ZSM-5 zeolite is developed to enhance the catalytic performance in a hydrocracking reaction. The generated mesopores and mesoporous channels in the new catalyst supply more opportunities for reactant accessing the active sites according to the better mass transfer and diffusion. Meanwhile, the acidity of the mesoporous catalyst is also weakened because of the removal of $\mathrm{Si}$ and $\mathrm{Al}$ species from its MFI structure, which makes the products distribution drift to more valued chemicals such as olefins. In the modified mesoporous ZSM-5 zeolites via different metallic promoters, the olefins' selectivity increases as the alkalinity of the catalyst increases. The reason for this is that the formed olefins will be further hydrogenated into corresponding alkanes immediately over the extremely acidic zeolite catalyst. Hence, the moderate alkalinity will limit this process, while at the same time the remaining olefins products will too. Furthermore, the Pd-based mesoporous ZSM-5 zeolite shows an excellent n-decane conversion and high propane selectivity due to the occurrence of hydrogen spillover via the Pd promoter. The phenomenon of hydrogen spillover supplies more chemisorbed sites of hydrogen atoms for hydrocracking and hydrogenating in this reaction. In short, this study explores the important effect factors in n-decane hydrocracking reaction activity and products distribution. It also shows a potential for the further industrial application of petroleum-derived fuel hydrocracking according to the optimized products distribution under metallic promoted mesoporous zeolite.
\end{abstract}

Keywords: hydrocracking; n-decane; ZSM-5 zeolite; mesoporous catalyst; olefin

\section{Introduction}

The cracking process is used to convert high molecules into lower molecular weight products by breaking the $\mathrm{C}-\mathrm{C}$ bond. Typically, industrial hydrocracking is carried out in two packed bed reactors. The first step is to remove the nitrogen- and sulfur-containing compounds. The long carbon chain molecules are hydroisomerized and cracked in the following, second step. This is an important technology in petroleum upgrading and plastic conversion [1-5]. Nowadays, the high valued lower molecular weight products can be obtained via an indirect route from coal or biomass conversion [6-11]. However, the complex technological process and formed abundant side products make it impossible, so far, to compare its economy with petroleum cracking. At present, the world is heavily dependent on liquid fuels such as petroleum; this also shows a growing tendency for lower molecular weight products demand. Meanwhile, sulfur- and nitrogen-containing compounds can be eliminated via the hydrocracking route, which seems to be an environment-friendly way for the synthesis of valued 
lower molecular weight products from the heavy constituents in the crude oil [12]. Thus, how to make effective utilization of petroleum is one of the greatest challenges in the 21st century.

In addition, hydrocracking, as a vital technological process for petroleum upgrading, is a classic bifunctional catalytic reaction, which has been widely studied since the last century [12]. It includes two processes to realize a complete reaction. The first step is a dehydrogenating process, and the second step is a hydrogenating step. In other words, the long chain alkanes will be isomerized at first, and then cracked into olefins with high energy in the first step, which is a dehydrogenating process. The cracked olefins will be continuously hydrogenated into corresponding alkanes in the second step. Along with the rapid evolution of the times, the demand for chemical products has also become pluralistic. Therefore, to obtain the specified and desired chemicals from petroleum or petroleum-derived fuels is still something that must be deeply studied.

Moreover, owing to environmental restrictions covered in several legislations throughout the world, non-polluting and atom-efficient catalytic technologies are much sought after. In the previous studies, numerous catalysts have been used in the hydrocracking reaction. For instance, Ni, Co, Mo metallic or sulfide catalysts are widely used in the past years. Nevertheless, the catalytic performance of common metals-based catalysts is still not good enough $[1,2,5,12]$. Zeolite has, as a more effective and environmental catalyst, been recently used in industrial applications. Zeolite is a well-known catalyst of its high surface area, with a high hydrothermal and thermal stability [13-17]. It hosts strong Bronsted and Lewis acid sites in the structural pores of molecular dimensions. The structural pores of the molecular dimension possess a shape selectivity for particular products. These unique properties are responsible for its application as a catalyst in many major chemical reaction processes.

ZSM-5 zeolite is a typical high silica zeolite, which has been first synthesized by Argauer and Landolt from Mobil Oil Corporation, in 1972 [18-23]. The most common preparation method for ZSM-5 is a hydrothermal synthesis by using organic compounds as a template. ZSM-5 is an MFI hierarchically structured material with a pore size of 5.1-5.6 ̊. Due to its unique shape selectivity, solid acidity, ion exchange ability, pore size, thermal stability and structural network, ZSM-5 has been widely used as catalysts and sorbents in the petroleum and petrochemical industry. The catalytic and sorption properties of the zeolite are often influenced by their crystal size. The acidity of ZSM-5 zeolite has a significant effect on the reaction path and product distribution in the reaction. However, the diffusional limitations are frequently observed in the conversion of large molecules. Except for ZSM- 5 zeolites, $\beta$ and $Y$ type zeolites are used in the hydrocracking reaction. However, the extremely strong acidity of other types of zeolite makes the products distribution hard to control. Moreover, the overly strong acidity will also accelerate the process of carbon deposition, affecting the catalyst's lifetime. Therefore, in our study, the ZSM- 5 zeolite is chosen as the hydrocracking catalyst.

In this study, $\mathrm{n}$-decane is used as a model compound to represent petroleum or petroleum-derived fuels $[4,24,25]$. Even though the decane is $\sim 11.4 \AA$ long, it has a strip shape, which can get through the 5.1-5.6 ̊ network in the ZSM-5 zeolite. Besides, the decane molecule can be isomerized and cracked into shorter carbon-chain hydrocarbons in its framework. To improve the catalyst activity in the large molecules' hydrocracking reaction, the mesoporous ZSM-5 zeolite is designed for a better mass transfer and diffusion of reactant [13,26-31]. Acid leaching is performed to dissolve the $\mathrm{Al}$ species from the MFI framework of the ZSM-5 zeolite. Meanwhile, alkali leaching must also necessarily be conducted to dissolve the Si species. Then, the mesoporous ZSM-5 zeolite is obtained in order to supply more active sites to attach the reactant of $n$-decane in the hydrocracking reaction. According to the pluralistic demand for chemical products, several metallic promoters are also introduced to tune the products' distribution [32-39]. The conversion to light olefins $\left(C_{2}=\right.$ to $\left.C_{5}{ }^{=}\right)$has attracted immense interest over a long period due to its merits, since light olefins are playing more important roles in the chemical industry. It is widely used in organic chemicals with the largest production volumes all over the world. Hence, light olefins seem to be ideal products in the n-decane hydrocracking reaction $[6,7,10,11]$. Through the above methods, the relationship between the characteristics of ZSM- 5 zeolite and the catalytic performance of n-decane hydrocracking are studied. In addition, the effect 
factors for product distribution are also well investigated in this research. Importantly, it guides the design of catalysts in the further industrial application of petroleum-derived fuels hydrocracking according to the excellent reaction results of optimized products' distribution under metallic promoted mesoporous zeolite catalysts.

\section{Results and Discussion}

\subsection{Prophase Research on n-Decane Hydrocracking}

At the start of this study, the conversion of n-decane hydrocracking at different temperatures was evaluated over the Z-100 catalyst, as shown in Figure 1. Zeolite ZSM-5 shows a good hydrocracking ability, especially at a higher temperature. As the temperature increases, zeolite ZSM- 5 becomes more markedly active in the n-decane hydrocracking process. This indicates that it is thermodynamically advantageous at higher temperatures. The conversion of n-decane rises from $48.2 \%\left(300{ }^{\circ} \mathrm{C}\right)$ to $79.8 \%$ $\left(400^{\circ} \mathrm{C}\right)$. Zeolite ZSM-5 has a good stability and activity at a high temperature according to its specific structure. Hence, $400{ }^{\circ} \mathrm{C}$ is implemented as the reaction condition in the following research.

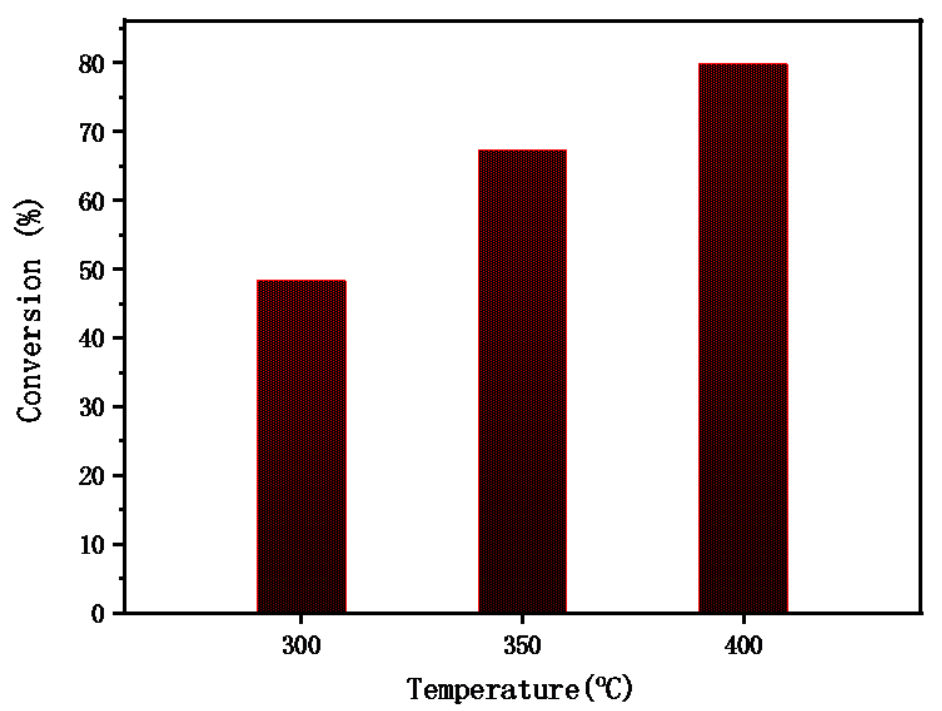

Figure 1. The conversion of n-decane at different temperatures over $\mathrm{Z}-100$. The reaction conditions: Catalyst weight $=0.3 \mathrm{~g}, \mathrm{~F}_{\mathrm{C} 10}=0.03 \mathrm{~g} / \mathrm{min}, \mathrm{F}_{\text {gas }}=20 \mathrm{~mL} / \mathrm{min}$, Pressure $=0.1 \mathrm{MPa}$.

Then, three types of ZSM-5 zeolites with different $\mathrm{Si} / \mathrm{Al}$ molar ratios are compared and evaluated in the n-decane hydrocracking reaction. The $\mathrm{SiO}_{2} / \mathrm{Al}_{2} \mathrm{O}_{3}$ ratio of the catalysts are 24, 100 and 1500, denoted as Z-24, Z-100 and Z-1500, respectively.

Figure 2 and Table 1 show the conversion and selectivity of Z-24, Z-100 and Z-1500 in the $\mathrm{n}$-decane cracking reaction. There is no activity of the $Z-1500$ catalyst in the reaction. This is because Z-1500 has no hydroisomerization and hydrogenation ability for cracking n-decane, according to its relatively low acidity, which is similar to $\mathrm{SiO}_{2}$. In comparison, the highest n-decane conversion, at $82.1 \%$, is obtained over the Z-24 catalyst. Meanwhile, the selectivity of olefin is only $6.7 \%$, as shown in Figure 2a. It is concluded that Z-24 has the highest hydrogenation ability. In the products distribution, shorter carbon chains and fewer olefins are obtained on zeolite Z-24 than on the other two catalysts. In Figure $2 b$, the catalyst of $Z-100$ also provides a good catalytic performance in n-decane. Nevertheless, the n-decane conversion of $79.8 \%$ over the Z-100 catalyst is slightly lower than that over the Z-24 catalyst. The selectivity of olefins $(11.2 \%)$ is much higher. Among the products, olefins seem to be a more valuable product. Thus, the $\mathrm{Z}-100$ catalyst with a $\mathrm{SiO}_{2} / \mathrm{Al}_{2} \mathrm{O}_{3}$ ratio of 100 is used below due to its good catalytic performance in n-decane. 
(a)

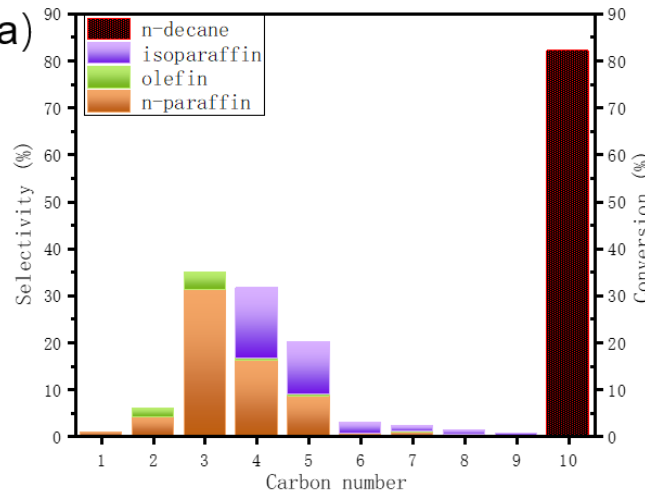

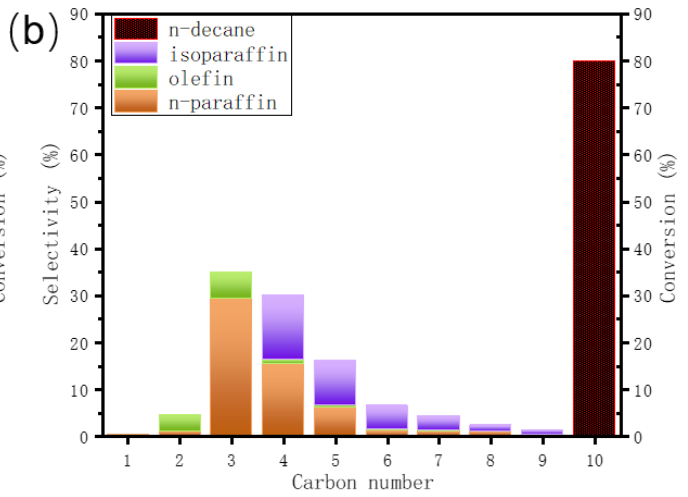

Figure 2. The conversion of the catalytic cracking of n-decane and the products distribution over (a) Z-24 and (b) Z-100. The reaction conditions: Catalyst weight $=0.3 \mathrm{~g}, \mathrm{~F}_{\mathrm{C} 10}=0.03 \mathrm{~g} / \mathrm{min}, \mathrm{F}_{\text {gas }}=20 \mathrm{~mL} / \mathrm{min}$, Reaction temperature $=400{ }^{\circ} \mathrm{C}$, Pressure $=0.1 \mathrm{MPa}$.

Table 1. The conversion of the catalytic cracking of n-decane and the products distribution a

\begin{tabular}{|c|c|c|c|c|c|c|c|c|c|c|c|c|c|c|}
\hline \multirow{2}{*}{ Catalyst } & \multirow{2}{*}{$\begin{array}{c}\text { Conversion } \\
(\%)\end{array}$} & \multicolumn{13}{|c|}{ Products Selectivity (\%) } \\
\hline & & $\mathrm{C}_{1}$ & $\mathrm{C}_{2}$ & $\mathrm{C}_{2}=$ & $\mathrm{C}_{3}$ & $\mathrm{C}_{3}=$ & $\mathrm{n}-\mathrm{C}_{4}$ & $\mathrm{C}_{4}=$ & $\mathrm{i}-\mathrm{C}_{4}$ & $\mathrm{n}-\mathrm{C}_{5}$ & $\mathrm{C}_{5}=$ & $\mathrm{i}-\mathrm{C}_{5}$ & $\mathrm{C}_{6}-\mathrm{C}_{9}$ & Olefins \\
\hline Z-24 & 82.1 & 0.8 & 4.0 & 2.0 & 31.2 & 3.7 & 16.1 & 0.5 & 15.0 & 8.5 & 0.4 & 11.2 & 6.6 & 6.7 \\
\hline Z-100 & 79.8 & 0.3 & 1.0 & 3.5 & 29.2 & 5.6 & 15.4 & 0.9 & 13.8 & 6.1 & 0.5 & 9.5 & 14.2 & 11.2 \\
\hline Z-1500 & 0 & - & - & - & - & - & - & - & - & - & - & - & - & - \\
\hline
\end{tabular}

a Reaction conditions: Catalyst weight $=0.3 \mathrm{~g}, \mathrm{~F}_{\mathrm{C} 10}=0.03 \mathrm{~g} / \mathrm{min}, \mathrm{F}_{\text {gas }}=20 \mathrm{~mL} / \mathrm{min}$, Reaction temperature $=400^{\circ} \mathrm{C}$, Pressure $=0.1 \mathrm{MPa}$.

The crystalline structure of catalysts can be confirmed using X-ray analysis. Figure 3 shows the X-ray diffraction (XRD) patterns of the ZSM-5 zeolites with different $\mathrm{SiO}_{2} / \mathrm{Al}_{2} \mathrm{O}_{3}$ molar ratios. The typical sole presence of the MFI framework is observed on the three samples. All samples give similar XRD patterns, which agrees well with those reported in the references. No other phase is found in all of the samples, confirming that the structure and crystallinity has not changed. Even though the crystalline structure and components are same in the three catalysts, they show obviously different catalytic performances in the n-decane hydrocracking reaction, suggesting that the different acidities supplied by the ZSM- 5 zeolites of different $\mathrm{SiO}_{2} / \mathrm{Al}_{2} \mathrm{O}_{3}$ molar ratios might be a crucial factor in the n-decane cracking reaction.

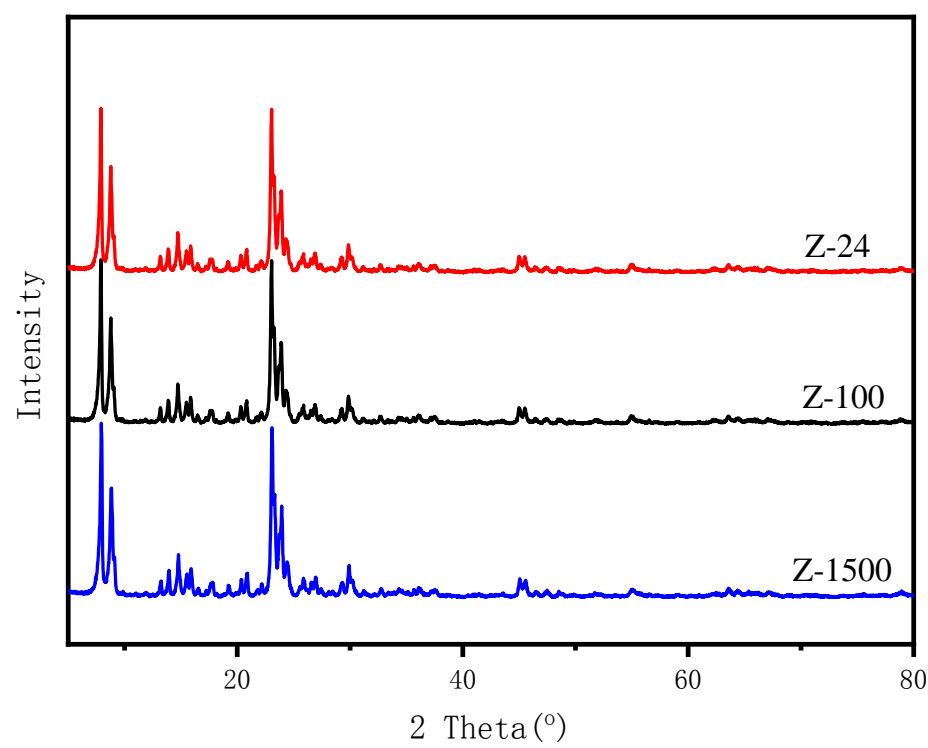

Figure 3. The XRD patterns of the zeolites with different molar ratios of $\mathrm{Si} / \mathrm{Al}$. 
The texture parameters of ZSM-5 zeolites with different $\mathrm{SiO}_{2} / \mathrm{Al}_{2} \mathrm{O}_{3}$ molar ratios are listed in Table 2, and the $\mathrm{N}_{2}$ sorption isotherms of the various catalysts are displayed in Figure 4. Interestingly, for these three catalysts, mesopores appeared. These might be the piled mesopores caused by the crystal packing between the $\mathrm{Si}$ and $\mathrm{Al}$ in the ZSM- 5 zeolites. Based on Table 1, by increasing the $\mathrm{SiO}_{2} / \mathrm{Al}_{2} \mathrm{O}_{3}$ molar ratio of the samples, the surface areas of the micropores increase. The surface areas of the piled mesopores decrease a lot from 283.9 to $77.1 \mathrm{~m}^{2} / \mathrm{g}$ because of the $\mathrm{Al}$ amount being extremely low in the Z-1500 catalyst. For the Z-1500 catalyst, the $\mathrm{Al}$ element is too low to be detected, so the detailed $\mathrm{SiO}_{2} / \mathrm{Al}_{2} \mathrm{O}_{3}$ ratio of $\mathrm{Z}-1500$ could not be provided by the EDX.

Table 2. The physical properties of different catalysts.

\begin{tabular}{|c|c|c|c|c|c|c|}
\hline \multirow{2}{*}{ Sample } & \multicolumn{2}{|c|}{ Surface Area $\left(\mathrm{m}^{2} / \mathrm{g}\right)$} & \multicolumn{2}{|c|}{ Pore Volume $\left(\mathrm{cm}^{3} / \mathrm{g}\right)$} & \multirow{2}{*}{$\begin{array}{l}\text { Average Pore } \\
\text { Diameter }(\mathrm{nm})\end{array}$} & \multirow{2}{*}{$\begin{array}{c}\mathrm{SiO}_{2} / \mathrm{Al}_{2} \mathrm{O}_{3} \\
\text { Molar Ratio a }\end{array}$} \\
\hline & Micro & Meso & Micro & Meso & & \\
\hline Z-24 & 158.4 & 283.9 & 0.20 & 0.20 & 3.49 & 22.6 \\
\hline Z-100 & 160.6 & 266.5 & 0.14 & 0.23 & 3.47 & 97.3 \\
\hline Z-1500 & 306.6 & 77.1 & 0.18 & 0.10 & 2.94 & - \\
\hline
\end{tabular}

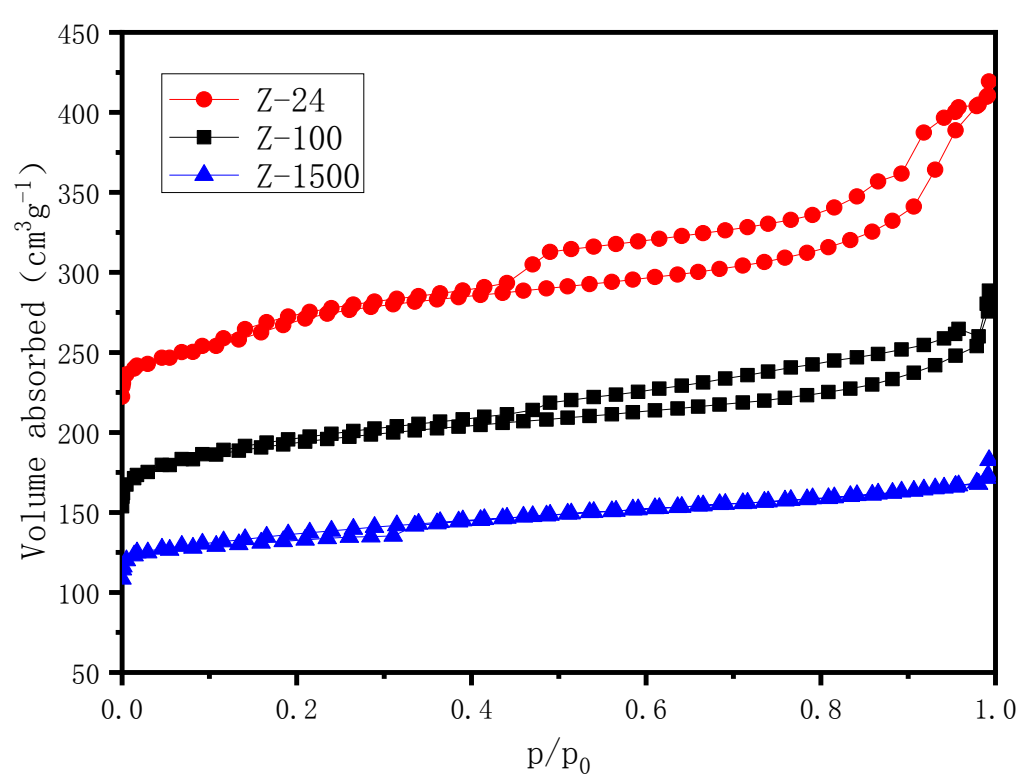

Figure 4. The $\mathrm{N}_{2}$ sorption isotherms of zeolites with different molar ratios of $\mathrm{Si} / \mathrm{Al}$.

In brief, zeolite ZSM-5 exhibits a good catalytic performance in the hydrocracking of n-decane. By increasing of $\mathrm{SiO}_{2} / \mathrm{Al}_{2} \mathrm{O}_{3}$ molar ratio, the total acid sites of $\mathrm{ZSM}-5$ may decrease. The dehydrogenation ability increases and hydrocracking ability decreases. From the reaction results above, it is inferred that the ZSM-5 with a moderate higher $\mathrm{SiO}_{2} / \mathrm{Al}_{2} \mathrm{O}_{3}$ molar ratio is helpful for obtaining olefins; a low $\mathrm{SiO}_{2} / \mathrm{Al}_{2} \mathrm{O}_{3}$ molar ratio for the catalyst favors the cracking of the carbon-carbon bond of the n-decane, because the acidity of the catalyst plays a crucial role in the hydrocracking of the n-decane reaction.

\subsection{Design of Mesoporous ZSM-5 Zeolite}

To improve the catalytic activity and produce more valuable products in the n-decane hydrocracking reaction, the mesoporous ZSM-5 zeolite is synthesized via acid and alkali leaching, denoted as Z-100-M. Figure 5 shows the XRD patterns of the ZSM- 5 zeolite treated by acid and alkali leaching. Similar $X$-ray diffraction patterns can be found for the two catalysts. In comparison to the Z-100 catalyst, no new phases appeared in the Z-100-M catalyst. The results of the XRD patterns point out that the Z-100-M catalyst bulk structure is not obviously changed and that the crystalline structure is not destroyed. 


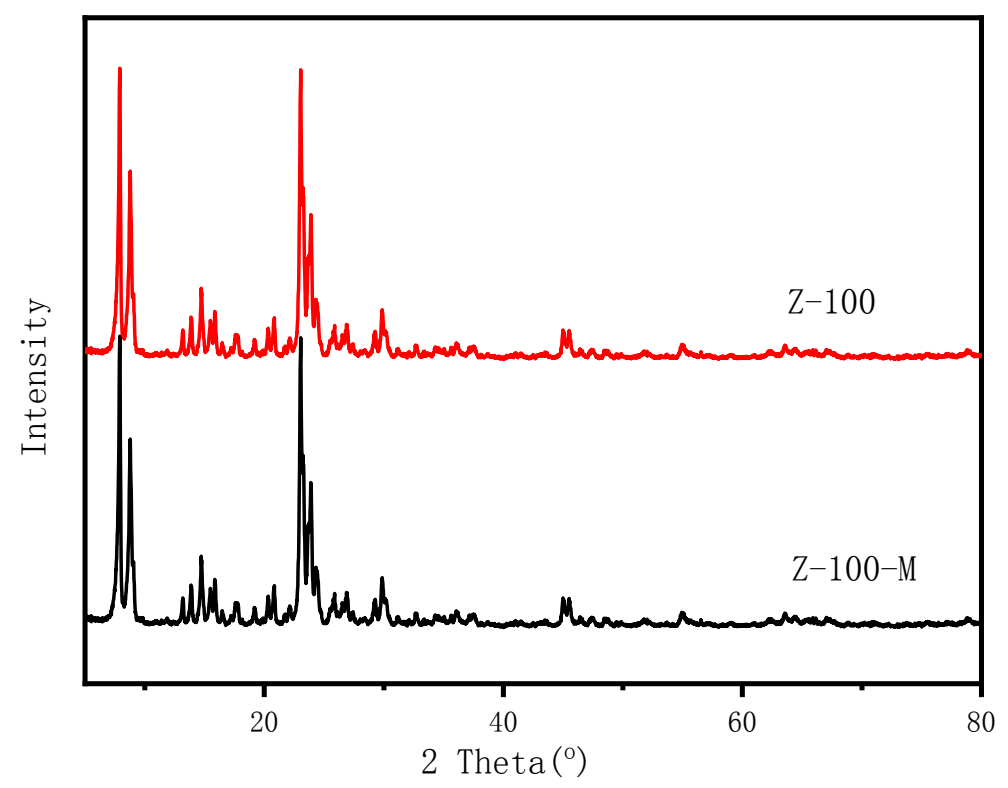

Figure 5. The XRD patterns of different types of ZSM-5 zeolite.

Owing to the fact that XRD only verifies the structure of bulk phases, SEM technology is further operated to investigate the microstructure of the catalysts' surface (Figure 6). As shown in Figure 6a-d, the particle sizes of the Z-100 and Z-100-M catalysts are similar. In the higher magnification images of Figure $6 \mathrm{~b}, \mathrm{~d}$, the surface of the $\mathrm{Z}-100-\mathrm{M}$ catalyst is clean and intact, confirming that the Z-100-M catalyst is not corroded by acid and alkali leaching during the process of mesopore generation. However, it is still difficult to distinguish from these images whether the mesopores are successful forming or not. Therefore, further studying of the characterization must be conducted in this research.
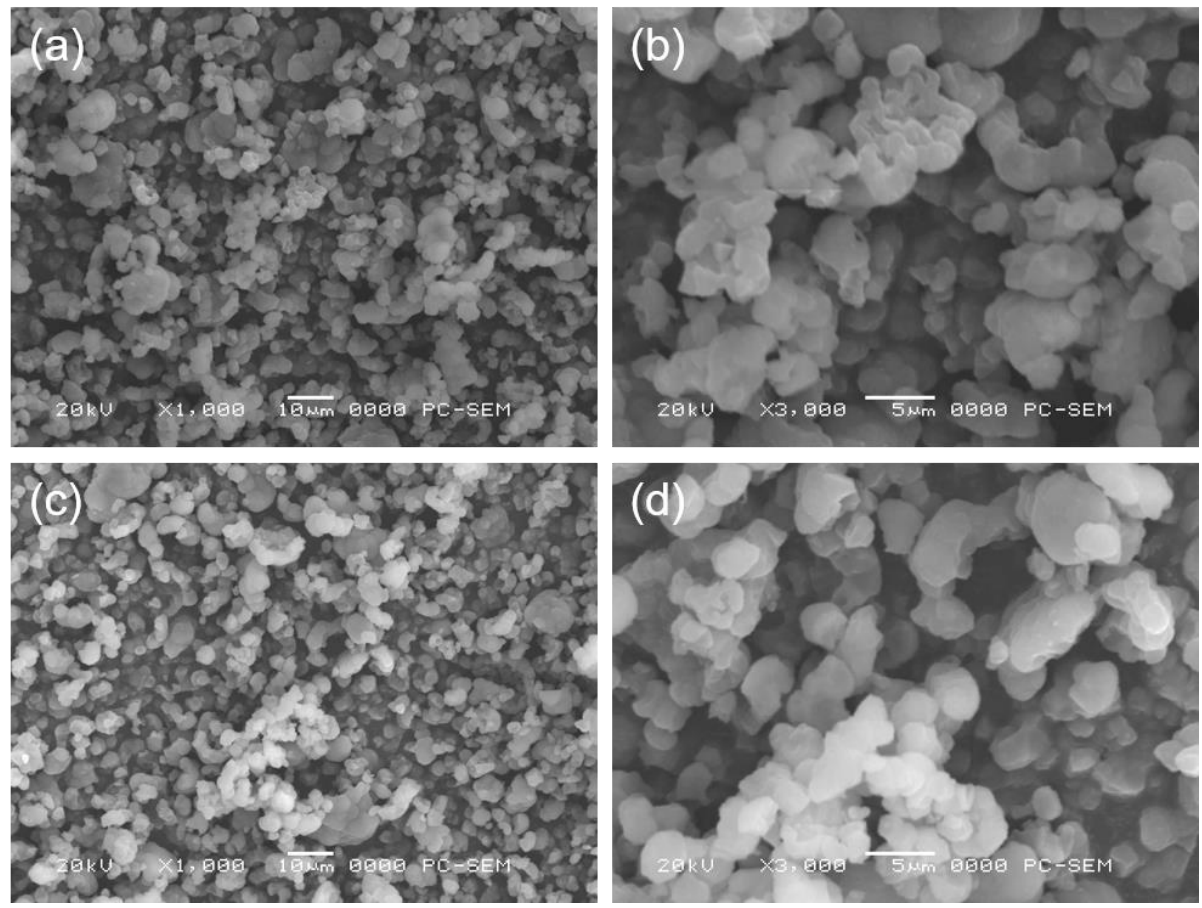

Figure 6. The SEM images of (a) Z-100 under a lower magnification, (b) Z-100 under a higher magnification, (c) Z-100-M under a lower magnification, and (d) Z-100-M under a higher magnification. 
TEM is a sensitive characterization technology for visually identifying the microstructure of catalysts. Figure 7a shows the TEM picture of Z-100, and there are no mesopores or mesoporous channels in the Z-100 catalyst. As illustrated in Figure 7b, several rifts appear at Z-100-M, which are ascribed to the mesoporous channels. In the enlarged image of Figure 7c, plenty of mesoporous channels are formed in the Z-100-M catalyst. It is also clearly found that the formed mesopores are relatively uniform in the $\mathrm{Z}-100-\mathrm{M}$ catalyst, and they are presented by the nearly transparent drop-like dots (Figure $7 \mathrm{~d}$ ). The results indicate that the mesopores are successfully formed in the Z-100-M catalyst by our catalyst preparation method. Moreover, the sizes of most mesopores are close to $20 \mathrm{~nm}$, as shown in the insert of Figure 7d. From our perspective, the generated mesopores and mesoporous channels will boost the n-decane hydrocracking process due to the supplied larger channels for reactant diffusion and more active sites in the Z-100-M catalyst.
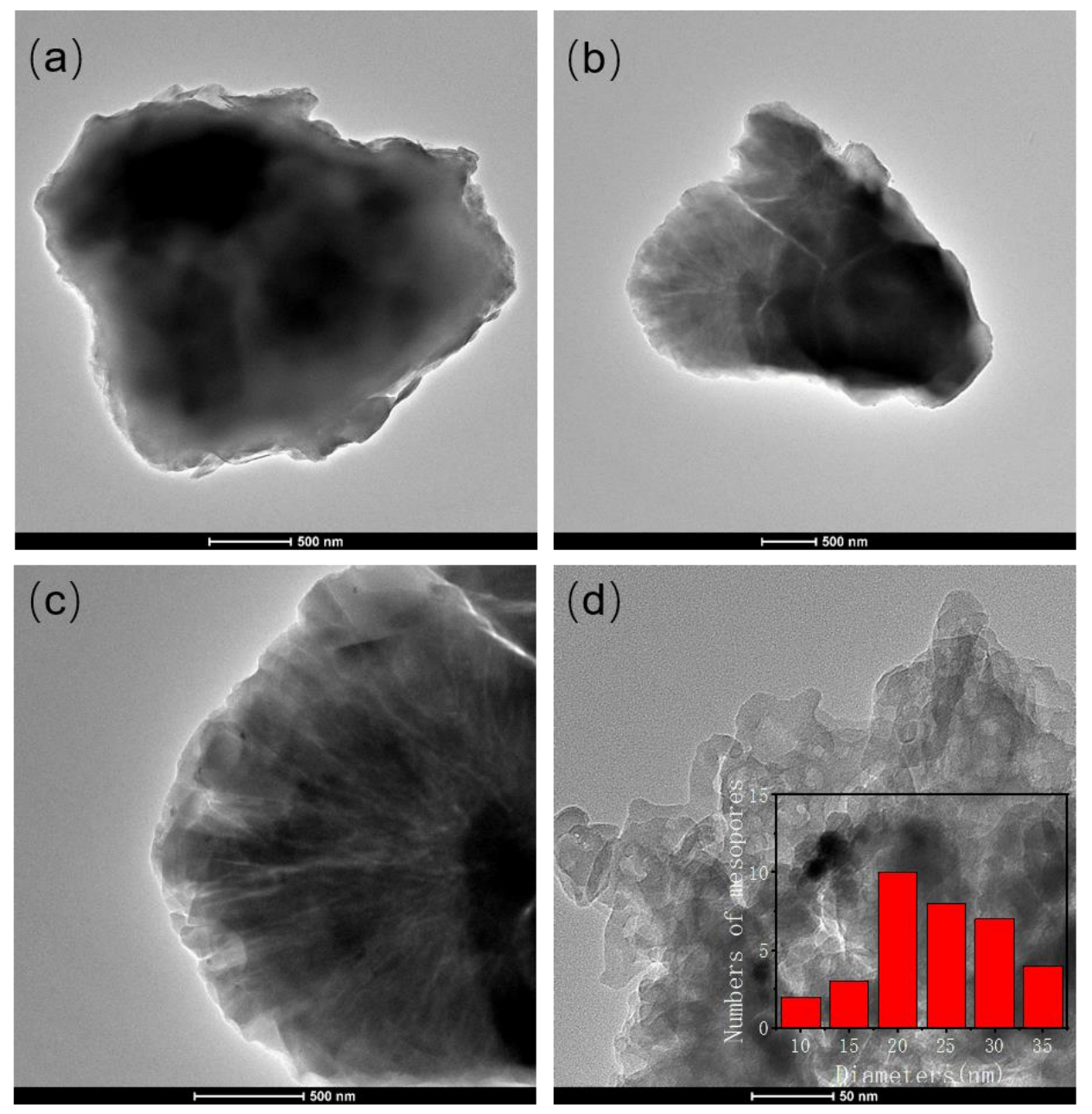

Figure 7. The TEM images of different types of ZSM-5. (a) Z-100, (b) Z-100-M, (c) Z-100-M under a higher magnification, and (d) high-resolution TEM images of Z-100-M.

The BET analysis also gives more evidences for successful forming mesopores in the Z-100-M catalyst, as shown in Figure 8 and Table 3. For Z-100, mesopores appeared. These might be the piled mesopores caused by the crystal packing in Z-100. For Z-100-M, the surface area of the mesopores increases, differing from the piled mesopores in Z-100. This is because the amount of micropores decreases (Table 3) and a peak corresponding to the mesopores at about $20 \mathrm{~nm}$ is observed (Figure 8b). It is believed that the acid leaching, together with the alkali leaching, is more effective for generating the inner mesopores on the zeolite ZSM-5. Moreover, the average pores' size for Z-100-M is also enlarged from 3.47 to $3.99 \mathrm{~nm}$, indicating that the new mesopores are formed in the Z-100-M catalysts. 
(a)

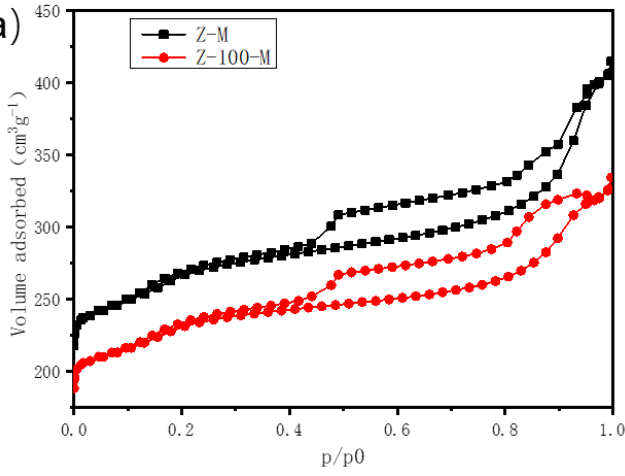

(b)

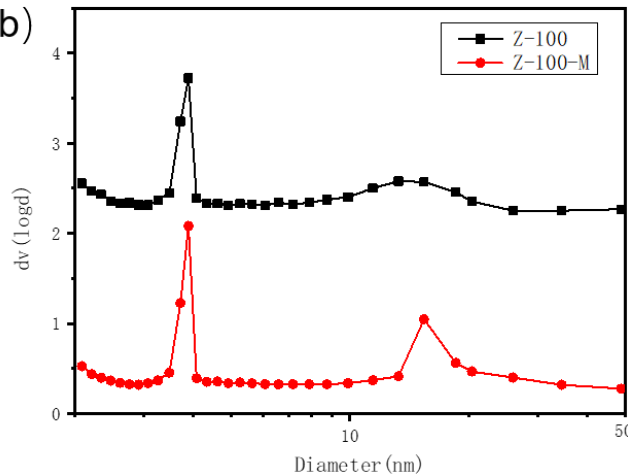

Figure 8. The BET analysis of the Z-100 and Z-100-M catalysts. The (a) $\mathrm{N}_{2}$ sorption isotherms and (b) pore size distributions.

Table 3. The physical properties of different catalysts.

\begin{tabular}{|c|c|c|c|c|c|c|}
\hline \multirow{2}{*}{ Sample } & \multicolumn{2}{|c|}{ Surface Area $\left(\mathrm{m}^{2} / \mathrm{g}\right)$} & \multicolumn{2}{|c|}{ Pore Volume $\left(\mathrm{cm}^{3} / \mathrm{g}\right)$} & \multirow{2}{*}{$\begin{array}{l}\text { Average Pore } \\
\text { Diameter }(\mathrm{nm})\end{array}$} & \multirow{2}{*}{$\begin{array}{c}\mathrm{SiO}_{2} / \mathrm{Al}_{2} \mathrm{O}_{3} \\
\text { Molar Ratio }\end{array}$} \\
\hline & Micro & Meso & Micro & Meso & & \\
\hline Z-100 & 160.6 & 266.5 & 0.14 & 0.23 & 3.47 & 97.3 \\
\hline Z-100-M & 108.9 & 306.9 & 0.15 & 0.30 & 3.99 & 90.8 \\
\hline
\end{tabular}

${ }^{\text {a }} \mathrm{The} \mathrm{SiO}_{2} / \mathrm{Al}_{2} \mathrm{O}_{3}$ molar ratio was quantified by EDX analysis.

In the previous reaction results of different $\mathrm{SiO}_{2} / \mathrm{Al}_{2} \mathrm{O}_{3}$ molar ratio catalysts, it was inferred that the acidity of the catalyst plays a crucial role in the n-decane hydrocracking reaction. Thus, the $\mathrm{NH}_{3}-\mathrm{TPD}$ characterization is performed to confirm the relationship between the acidity and catalytic performance over the two catalysts. Figure 9 shows the acidity of the Z-100 and Z-100-M catalysts. There is a downshift tendency of the temperature of the peaks in the $Z-100-M$ catalyst, indicating that the acid strength of Z-100-M is weaker than that of the Z-100 catalyst. Meanwhile, the amount of acidity also decreases in the Z-100-M in comparison to the Z-100 catalyst according to its lower intensity of peaks. The reason for this is that the $\mathrm{Al}$ and $\mathrm{Si}$ of the ZSM- 5 zeolite can be partially removed by acid leaching, together with alkali leaching, during the process of the mesopores' generation. Furthermore, the acidity of the zeolite is supplied by the strong interaction of the $\mathrm{Si}$ and $\mathrm{Al}$ components. As shown in Figure 9, the acidity of Z-100-M is only weakened a little by the acid and alkali leaching. Moreover, the moderately weaker acidity of the catalyst is beneficial for producing olefins in the n-decance hydrocracking reaction, rendering the products more valuable.

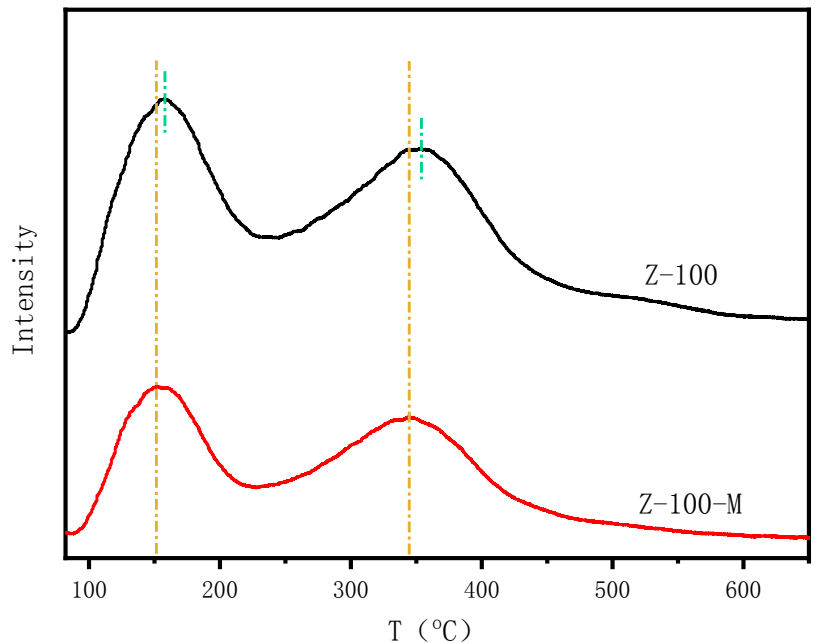

Figure 9. The $\mathrm{NH}_{3}-\mathrm{TPD}$ profiles of the mesoporous ZSM-5 and common ZSM-5 catalysts. 
Figure 10 and Table 4 show the conversion and selectivity of the different types of ZSM- 5 zeolites in the n-decane hydrocracking reaction. The results demonstrate that it has a better catalytic performance over the Z-100-M catalyst than over the Z-100 catalyst. In detail, the n-decane conversion of $88.6 \%$ over $Z-100-M$ is higher than that of $79.8 \%$ over the $Z-100$ catalyst. Even though the $Z-100$ catalyst possesses a stronger acidity for a higher hydrocracking ability in the reaction, the generated mesopores and mesoporous channels of the Z-100-M catalyst supply more active sites for activating the reactant, leading to a higher conversion being achieved in the $\mathrm{Z}-100-\mathrm{M}$ catalyst. Due to its specific characteristics of a better mass transfer and diffusion, the n-decane and long-chain byproducts can more easily be hydrocracked in the mesopores, making the products distribution drift to $C_{3}-C_{5}$. Moreover, the selectivity of the olefins is $33.7 \%$ over the mesoporous the ZSM-5 zeolite catalyst, which is much higher than that of $11.2 \%$ over the common ZSM-5 zeolite catalyst. This is because the ZSM- 5 zeolite is ascribed to a solid acid with Lewis and Bronsted acid sites. The long-chain hydrocarbons can be cracked into short-chain hydrocarbons through its strong acidity, while simultaneously immediately hydrogenating the formed alkenes into corresponding alkanes. In the two acid sites, the Bronsted acid plays a crucial role in this process over the Lewis acid. The removal of $\mathrm{Si}$ and $\mathrm{Al}$ in the $\mathrm{Z}-100-\mathrm{M}$ catalyst is beneficial for weakening the acidity of the ZSM-5 zeolite. Hence, the Z-100-M catalyst with a moderate acidity will be in favor of olefin production in comparison to the Z-100 catalyst. The result turns out to prove that designing the mesoporous Z-100-M catalyst is an effective way of improving the n-decane hydrocracking catalytic performance and of enhancing the value of the products.
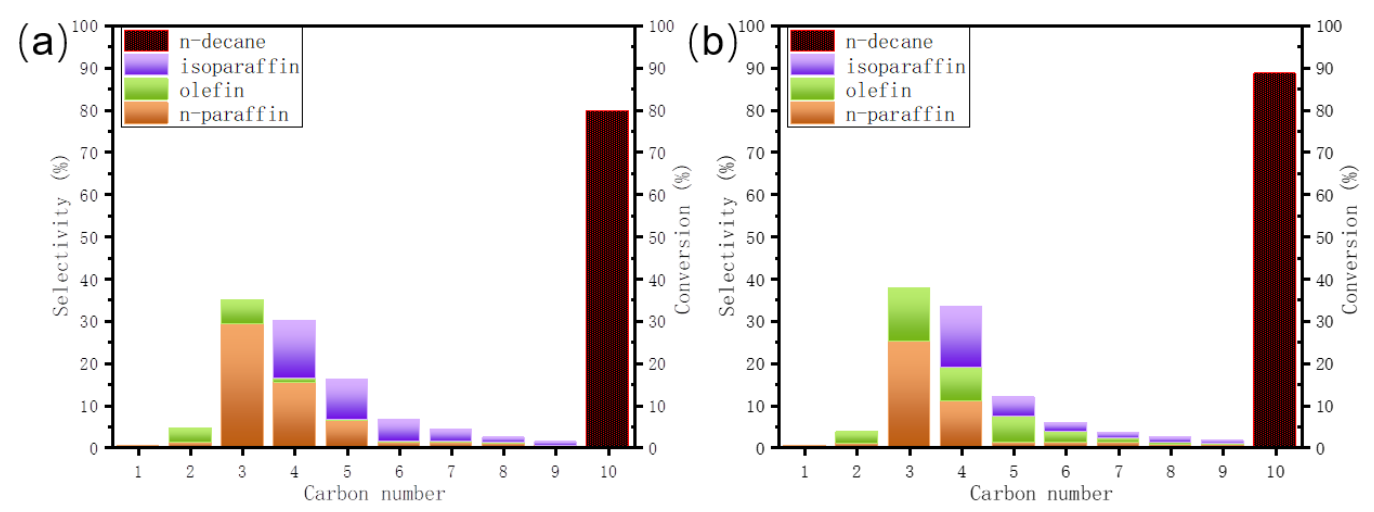

Figure 10. The conversion of the catalytic cracking of n-decane and the products distribution over (a) Z-100 and (b) Z-100-M. The reaction conditions: Catalyst weight $=0.3 \mathrm{~g}, \mathrm{~F}_{\mathrm{C} 10}=0.03 \mathrm{~g} / \mathrm{min}$, $\mathrm{F}_{\text {gas }}=20 \mathrm{~mL} / \mathrm{min}$, Reaction temperature $=400^{\circ} \mathrm{C}$, Pressure $=0.1 \mathrm{MPa}$.

Table 4. The conversion of the catalytic cracking of n-decane and the products distribution ${ }^{\mathrm{a}}$.

\begin{tabular}{|c|c|c|c|c|c|c|c|c|c|c|c|c|c|c|}
\hline \multirow{2}{*}{ Catalyst } & \multirow{2}{*}{$\begin{array}{c}\text { Conversion } \\
(\%)\end{array}$} & \multicolumn{13}{|c|}{ Products Selectivity (\%) } \\
\hline & & $\mathrm{C}_{1}$ & $\mathrm{C}_{2}$ & $\mathrm{C}_{2}=$ & $\mathrm{C}_{3}$ & $C_{3}=$ & $\mathrm{n}-\mathrm{C}_{4}$ & $\mathrm{C}_{4}=$ & $\mathrm{i}-\mathrm{C}_{4}$ & $n-C_{5}$ & $\mathrm{C}_{5}=$ & $\mathrm{i}-\mathrm{C}_{5}$ & $\mathrm{C}_{6}-\mathrm{C}_{9}$ & Olefins \\
\hline Z-100 & 79.8 & 0.3 & 1.0 & 3.5 & 29.2 & 5.6 & 15.4 & 0.9 & 13.8 & 6.1 & 0.5 & 9.5 & 14.2 & 11.2 \\
\hline Z-100-M & 88.6 & 0.3 & 0.9 & 2.7 & 25.2 & 12.6 & 10.9 & 8.0 & 14.5 & 1.1 & 6.2 & 4.6 & 13.0 & 33.7 \\
\hline
\end{tabular}

${ }^{a}$ Reaction conditions: Catalyst weight $=0.3 \mathrm{~g}, \mathrm{~F}_{\mathrm{C} 10}=0.03 \mathrm{~g} / \mathrm{min}, \mathrm{F}_{\text {gas }}=20 \mathrm{~mL} / \mathrm{min}$, Reaction temperature $=400{ }^{\circ} \mathrm{C}$, Pressure $=0.1 \mathrm{MPa}$.

Briefly, the mesoporous Z-100-M catalyst exhibits a better catalytic performance in the hydrocracking of n-decane. The well-designed mesoporous structure of this new ZSM-5 zeolite can easily accelerate the diffusion of reactants and products, while at the same time providing more effective active sites for hydrocracking $n$-decane. In the hydrocracking of $n$-decane under the Z-100-M catalyst, $\mathrm{n}$-decane can easily access the moderate acid sites of zeolite through mesopores for hydrocracking, enhancing the n-decane conversion and producing more valuable products. 


\subsection{Tuning the Products Distribution by Loading Metallic Promoters}

Based on the impact of the acidity in the products distribution, several metallic promoters such as alkaline-earth and noble metals have been introduced to optimize the products distribution, and they are denoted as Z-M-Mg, Z-M-Ca, Z-M-Sr and Z-M-Pd, respectively. The alkaline-earth metals are only used as promoters for the modification of the catalyst by changing its acidity. The alkaline-earth metals can weaken the acidity of the zeolite catalyst to enhance the olefin selectivity in the n-decane hydrocracking reaction. In the process of n-decane hydrocracking, the strong acidity of the catalyst is beneficial for initially cracking the $\mathrm{C}-\mathrm{C}$ bond. The acidity is also helpful for immediately hydrogenating the formed olefins into alkanes, while at the same time reducing the products value. Hence, the modification of the catalyst by alkaline-earth metals is an effective way of weakening the catalyst acidity to obtain more olefins in the n-decane hydrocracking reaction. The noble metal $\mathrm{Pd}$ is used as a catalyst promoter to change the properties of the zeolite catalyst. In addition, adding Pd into the zeolite catalyst is a good method for enhancing the catalyst utilization efficiency according to the $\mathrm{H}_{2}$ spillover on $\mathrm{Pd}$.

Each catalyst has been individually prepared by a typical impregnation method. Figure 11 shows the XRD patterns of the mesoporous ZSM-5 zeolite (Z-100-M) catalysts modified by different alkaline-earth and noble metals. Similar X-ray diffraction patterns corresponding to MFI can be found for the catalysts modified by these metals. The results of the XRD patterns point out that the catalysts' bulk structures show no obvious changes, indicating that the introduced promoters do not destroy the structure of the ZSM-5 zeolite. Meanwhile, the amounts of loaded metals are very low, and they are all well-dispersed on the zeolite surface; therefore, the characteristic peaks of the different metals are not observed.

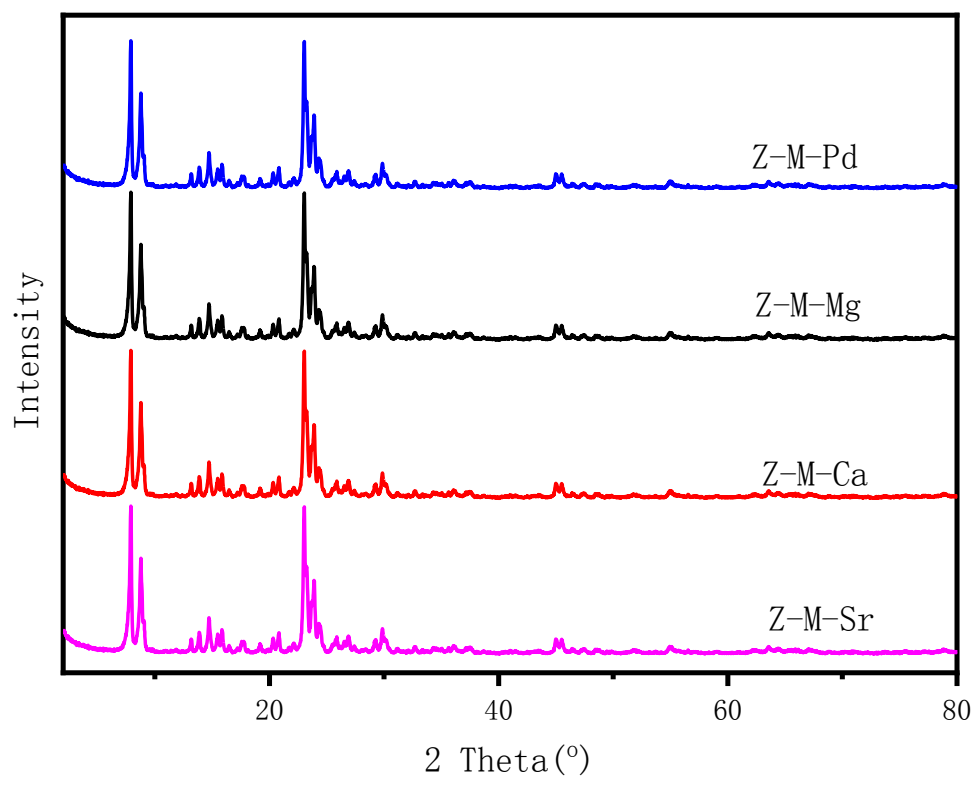

Figure 11. The XRD patterns of the mesoporous ZSM-5 zeolite modified by different metals.

The acidic properties of the different metallic-based mesoporous ZSM-5 zeolite catalysts are measured by $\mathrm{NH}_{3}-\mathrm{TPD}$, as shown in Figure 12. The results of the $\mathrm{NH}_{3}-\mathrm{TPD}$ patterns shows that the acidities of the zeolites become weaker when increasing the atomic number in the alkaline-earth metals. The alkalinity of the alkaline-earth metals partially covers the acid sites of ZSM-5 and effectively weakens the acidity of the mesoporous ZSM-5 zeolite. Among the catalysts of Z-M-Mg, Z-M-Ca and $\mathrm{Z}-\mathrm{M}-\mathrm{Sr}$, the acidity of $\mathrm{Z}-\mathrm{M}-\mathrm{Sr}$ is the lowest. However, after adding the noble metal Pd, the catalyst Z-Pd still possesses a high acidity, with two marked peaks of weak and strong acid sites. 


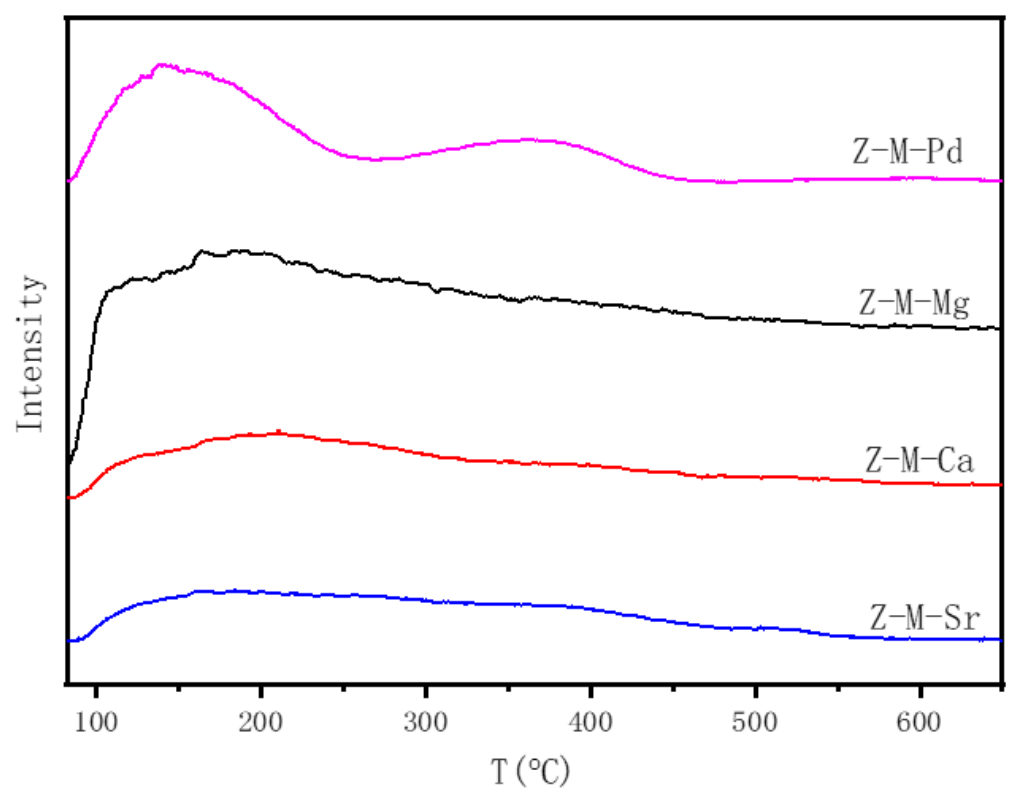

Figure 12. The $\mathrm{NH}_{3}$-TPD profiles of the mesoporous ZSM- 5 zeolite modified by different metals.

The texture parameters of the impregnated catalysts are listed in Table 5 and have been characterized by BET technology. After an impregnation with $3 \mathrm{wt} \%$ alkaline-earth metals $(\mathrm{Mg}, \mathrm{Ca}$, $\mathrm{Sr}$ ), the specific surface area of the mesopores were reduced by nearly half compared to Z-100-M, suggesting that the mesopores on the zeolite ZSM- 5 were blocked by these metallic promoters. There is no big difference among these three alkaline-earth modified catalysts ( $\mathrm{Z}-\mathrm{M}-\mathrm{Mg}, \mathrm{Z}-\mathrm{M}-\mathrm{Ca}, \mathrm{Z}-\mathrm{M}-\mathrm{Sr})$ in the results of the BET analysis either. The catalysts' activity might also be decreased in the n-decane hydrocracking reaction according to this phenomenon. Unlike the catalysts above, the loading amount of Pd is only $0.3 \mathrm{wt} \%$, so the high surface area of mesopores is observed in the Z-M-Pd catalyst. It shows similar texture parameters to the $\mathrm{Z}-100-\mathrm{M}$ catalyst, which indicates that the mesopores are not blocked in the Z-M-Pd catalyst.

Table 5. The physical properties of the different catalysts.

\begin{tabular}{|c|c|c|c|c|c|c|}
\hline \multirow{2}{*}{ Sample } & \multicolumn{2}{|c|}{ Surface Area $\left(\mathrm{m}^{2} / \mathrm{g}\right)$} & \multicolumn{2}{|c|}{ Pore Volume $\left(\mathrm{cm}^{3} / \mathrm{g}\right)$} & \multirow{2}{*}{$\begin{array}{l}\text { Average Pore } \\
\text { Diameter }(\mathrm{nm})\end{array}$} & \multirow{2}{*}{$\begin{array}{l}\text { Metal Amount } \\
\quad(w t \%)^{a}\end{array}$} \\
\hline & Micro & Meso & Micro & Meso & & \\
\hline $\mathrm{Z}-\mathrm{M}-\mathrm{Mg}$ & 181.8 & 156.8 & 0.08 & 0.30 & 4.44 & 2.7 \\
\hline $\mathrm{Z}-\mathrm{M}-\mathrm{Ca}$ & 194.6 & 172.8 & 0.08 & 0.34 & 4.60 & 2.6 \\
\hline $\mathrm{Z}-\mathrm{M}-\mathrm{Sr}$ & 204.2 & 161.6 & 0.07 & 0.32 & 4.29 & 2.9 \\
\hline Z-M-Pd & 108.9 & 305.8 & 0.13 & 0.29 & 4.01 & 0.3 \\
\hline
\end{tabular}

${ }^{\mathrm{a}}$ The amount of metallic promoters was quantified by EDX analysis.

The catalytic performances of alkaline-earth and noble metallic based catalysts in the n-decane hydrocracking reaction are shown in Figure 13 and Table 6. By adding these promoters, the n-decane conversion and products distribution are totally different. For the $\mathrm{Z}-\mathrm{M}-\mathrm{Mg}$, the $\mathrm{n}$-decane conversion decreases to $52.8 \%$ with many olefins being formed (50.7\%), which shows a good selectivity of valuable olefins. The decrease of the catalyst activity is affected by the partially blocked mesopores and is somehow influenced by the alkalinity of the metallic $\mathrm{Mg}$. In the n-decane hydrocracking reaction, the supplied acid sites are in favor of cracking the $\mathrm{C}-\mathrm{C}$ bond of long-chain alkanes. With an increase of the alkalinity in promoters, the n-decane conversion further decreases to $22.5 \%$ over the $\mathrm{Z}-\mathrm{M}-\mathrm{Sr}$. However, the olefins increase to $64.6 \%$ at most in the $\mathrm{Z}-\mathrm{M}-\mathrm{Sr}$ catalyst. This further demonstrates our previous views, which were that the alkalinity plays a crucial role in the olefin production rather than the acidity over the catalysts. Thus, in these three alkaline-earth metals modified catalysts, $\mathrm{Z}-\mathrm{M}-\mathrm{Mg}$ 
seems to be the best catalyst for the n-decane conversion into valuable products. This is because it not only possesses a moderate alkalinity to produce olefins but also has a moderate acidity to crack n-decane at the same time. Surprisingly, it shows diametrically opposite reaction results over the Z-M-Pd catalyst. The n-decane conversion is extremely high at $95.3 \%$; meanwhile, no olefins are produced in the products. The $\mathrm{N}$-alkanes selectivity is as high as $84.5 \%$, especially at $46.7 \%$ for propane. It is clearly shown that the products distribution drifts to lower hydrocarbons, as shown in Figure 13. The noble metal Pd is a sensitive element in many catalytic reactions due to its physicochemical properties. Even though the tiny Pd loading amount of $0.3 \mathrm{wt} \%$ is hardly enough to block the mesopores in the ZSM- 5 zeolite, the major reason leading to this phenomenon is the occurrence of a $\mathrm{H}_{2}$ spillover according to the specifics of $\mathrm{Pd}$. A hydrogen spillover is the surface migration of activated hydrogen atoms from a metal catalyst particle, on which they are generated onto the catalyst support [40-43]. For the Z-M-Pd catalyst, the activated hydrogen atoms spill to the surface of the mesoporous ZSM- 5 zeolite via the promoter Pd. Hence, the chemisorbed hydrogen atoms intensively attack the $\mathrm{C}-\mathrm{C}$ bond of long-chain alkanes, while at the same time further hydrogenating the formed olefins into alkanes immediately. Based on these reasons, the Z-M-Pd is used as an outstanding catalyst for alkanes synthesis, especially for propane. The low impregnation amount of Pd effectively enhances its economic value for further industrial applications. With regards to its potential for industrial applications, the Z-M-Pd catalyst will significantly reduce the energy consumption and cost of products separation.
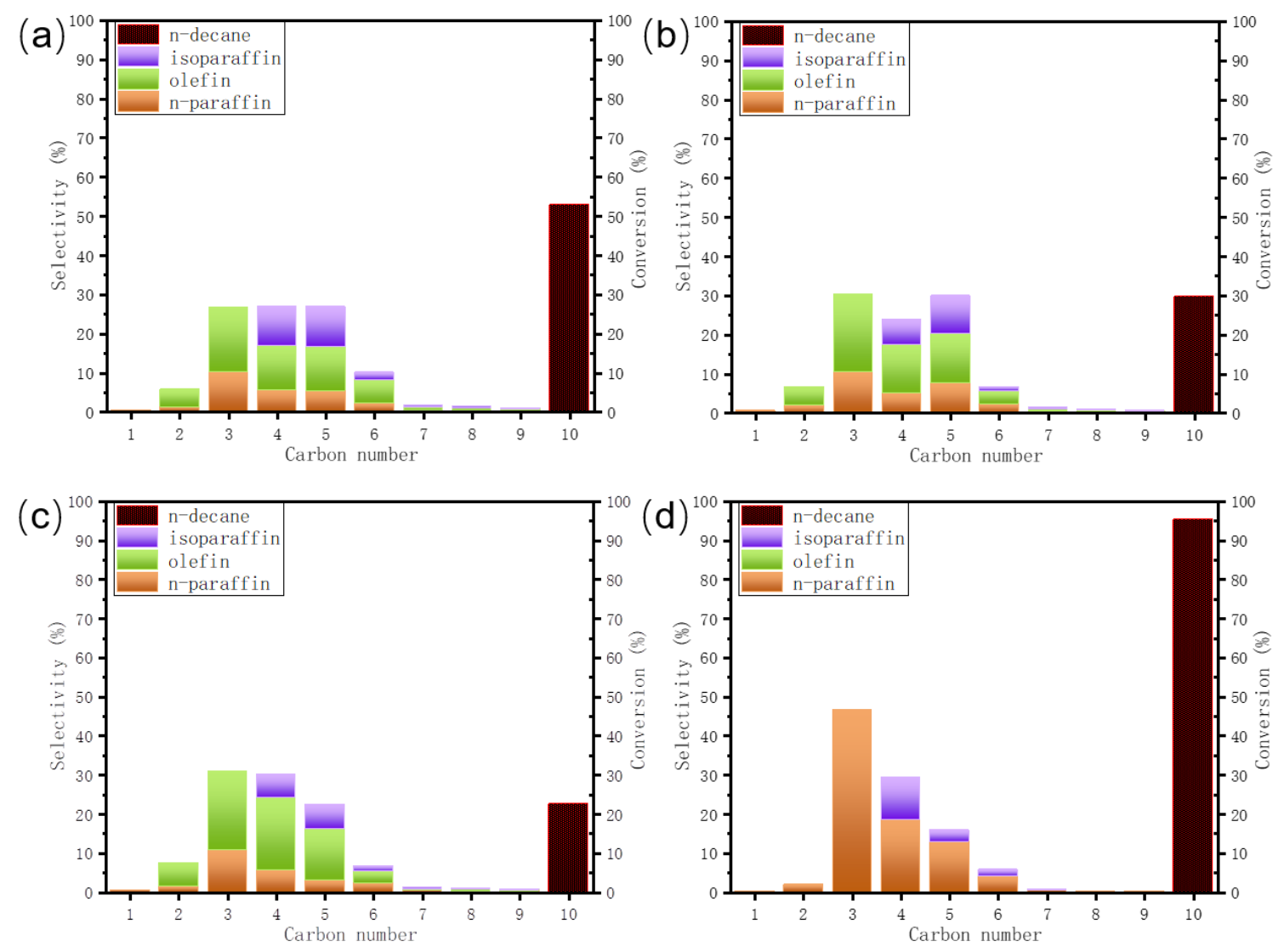

Figure 13. The conversion of the catalytic cracking of n-decane and the products distribution over (a) Z-M-Mg, (b) Z-M-Ca, (c) Z-M-Sr and (d) Z-M-Pd. The reaction conditions: Catalyst weight = $0.3 \mathrm{~g}$, $\mathrm{F}_{\mathrm{C} 10}=0.03 \mathrm{~g} / \mathrm{min}, \mathrm{F}_{\text {gas }}=20 \mathrm{~mL} / \mathrm{min}$, Reaction temperature $=400{ }^{\circ} \mathrm{C}$, Pressure $=0.1 \mathrm{MPa}$. 
Table 6. The conversion of the catalytic cracking of n-decane and the products distribution a

\begin{tabular}{|c|c|c|c|c|c|c|c|c|c|c|c|c|c|c|}
\hline \multirow{2}{*}{ Catalyst } & \multirow{2}{*}{$\begin{array}{c}\text { Conversion } \\
(\%)\end{array}$} & \multicolumn{13}{|c|}{ Products Selectivity (\%) } \\
\hline & & $\mathrm{C}_{1}$ & $\mathrm{C}_{2}$ & $\mathrm{C}_{2}=$ & $\mathrm{C}_{3}$ & $\mathrm{C}_{3}=$ & $\mathrm{n}-\mathrm{C}_{4}$ & $\mathrm{C}_{4}=$ & $\mathrm{i}-\mathrm{C}_{4}$ & $\mathrm{n}-\mathrm{C}_{5}$ & $C_{5}=$ & $\mathrm{i}-\mathrm{C}_{5}$ & $\mathrm{C}_{6}-\mathrm{C}_{9}$ & Olefins \\
\hline Z-M-Mg & 52.8 & 0.3 & 1.2 & 4.4 & 10.2 & 16.3 & 5.6 & 11.2 & 10.2 & 5.3 & 11.3 & 10.3 & 13.7 & 50.7 \\
\hline $\mathrm{Z}-\mathrm{M}-\mathrm{Ca}$ & 29.6 & 0.5 & 1.7 & 4.8 & 10.5 & 19.7 & 4.9 & 12.3 & 6.6 & 7.5 & 12.6 & 9.8 & 9.1 & 53.8 \\
\hline $\mathrm{Z}-\mathrm{M}-\mathrm{Sr}$ & 22.5 & 0.4 & 1.3 & 6.1 & 10.8 & 19.9 & 5.5 & 18.6 & 6.1 & 2.9 & 13.2 & 6.4 & 8.8 & 61.6 \\
\hline Z-M-Pd & 95.3 & 0.2 & 1.8 & 0 & 46.7 & 0 & 18.4 & 0 & 10.8 & 12.8 & 0 & 3.0 & 6.3 & 0 \\
\hline
\end{tabular}

In conclusion, after being modified by the noble metal $\mathrm{Pd}$, the process of catalytic hydrocracking becomes more thorough. It exhibits an outstanding n-decane conversion with an excellent propane selectivity in the catalytic hydrocracking reaction. In addition, the mesoporous zeolite ZSM- 5 catalysts, modified by alkaline-earth metals, exhibit a good catalytic selectivity of olefins in the hydrocracking of n-decane. Among all olefin products, the amount of propylene is the highest. With the catalysts' alkalinity increasing, the selectivity of propylene and other olefins increases. We can conclude that the alkalinity of catalysts significantly influences the selectivity of olefins. This is because a strong acidity of catalysts will hydrogenate the formed olefins into alkanes, while at the same time affecting the activity of the hydrocracking reaction.

\section{Materials and Methods}

\subsection{Catalyst Preparation}

\subsubsection{Mesoporous ZSM-5 Zeolite Preparation}

The pristine zeolite ZSM-5 (commercial ZSM-5 zeolite with $\mathrm{SiO}_{2} / \mathrm{Al}_{2} \mathrm{O}_{3}=100$ ) was denoted as Z-100. Then, we obtained a new mesoporous type catalyst through Z-100 zeolite.

The pristine zeolite ZSM- 5 was treated with a $0.17 \mathrm{~mol} / \mathrm{L}$ citric acid solution at $80{ }^{\circ} \mathrm{C}$ for $4 \mathrm{~h}$, and was subsequently washed with deionized water and dried at $120^{\circ} \mathrm{C}$ overnight. The zeolite treated with a citric acid solution was calcined at $550{ }^{\circ} \mathrm{C}$ for $3 \mathrm{~h}$. Then, the sample was treated with $0.1 \mathrm{~mol} / \mathrm{L}$ $\mathrm{NaOH}$ aqueous solution for $1 \mathrm{~h}$ at $80^{\circ} \mathrm{C}$ directly. The sample was then filtered, washed with deionized water and dried at $120^{\circ} \mathrm{C}$ overnight. The leached zeolite was finally exchanged with $\mathrm{NH}_{4} \cdot \mathrm{NO}_{3}$ solution, and then calcined at $550^{\circ} \mathrm{C}$ for $3 \mathrm{~h}$ to get H-ZSM-5 type zeolite, denoted as Z-100-M (Table 7).

Table 7. Different ZSM-5 zeolite catalysts.

\begin{tabular}{|c|c|c|}
\hline No. & Catalysts & Nomenclature \\
\hline 1 & The $\mathrm{SiO}_{2} / \mathrm{Al}_{2} \mathrm{O}_{3}$ ratio of 24 & $\mathrm{Z}-24$ \\
\hline 2 & The $\mathrm{SiO}_{2} / \mathrm{Al}_{2} \mathrm{O}_{3}$ ratio of 100 & $\mathrm{Z}-100$ \\
\hline 3 & The $\mathrm{SiO}_{2} / \mathrm{Al}_{2} \mathrm{O}_{3}$ ratio of 1500 & Z-1500 \\
\hline 4 & Mesoporous ZSM-5 zeolite & Z-100-M \\
\hline 5 & Mg based mesoporous ZSM- 5 zeolite & $\mathrm{Z}-\mathrm{M}-\mathrm{Mg}$ \\
\hline 6 & Ca based mesoporous ZSM- 5 zeolite & $\mathrm{Z}-\mathrm{M}-\mathrm{Ca}$ \\
\hline 7 & Sr based mesoporous ZSM-5 zeolite & $\mathrm{Z}-\mathrm{M}-\mathrm{Sr}$ \\
\hline 8 & Pd based mesoporous ZSM- 5 zeolite & $\mathrm{Z}-\mathrm{M}-\mathrm{Pd}$ \\
\hline
\end{tabular}

\subsubsection{Noble Metal-Based Zeolite Preparation}

The mesoporous type zeolite $\mathrm{Z}-100-\mathrm{M}$ was repeatedly ion-exchanged with ammonium nitrate at $40{ }^{\circ} \mathrm{C}$ several times. The metal incorporation was carried out in the ion exchange by $\operatorname{Pd}\left(\mathrm{NO}_{2}\right)_{2}\left(\mathrm{NH}_{3}\right)_{2}$. The zeolite $\mathrm{Z}-100-\mathrm{M}$ was loaded with $0.3 \mathrm{wt} \% \mathrm{Pd}$. The metal precursor was diluted in $50 \mathrm{~mL}$ of distilled water, and the obtained solution was added drop-wise to $1.5 \mathrm{~g}$ of the zeolite. After stirring the solution for $6 \mathrm{~h}$ at $40^{\circ} \mathrm{C}$, the water was removed into a rotary evaporator at $70^{\circ} \mathrm{C}$ under vacuum. 
Thereafter, the sample was dried at $120^{\circ} \mathrm{C}$ for $12 \mathrm{~h}$. Then, the sample was calcined at $550{ }^{\circ} \mathrm{C}$ for $3 \mathrm{~h}$ to get a Pd-based zeolite, denoted as Z-M-Pd (Table 7).

\subsubsection{Alkaline Earth Metal-Based Zeolite Preparation}

The prepared ZSM-5 zeolite catalyst Z-100-M was impregnated with nitrate solution: $\mathrm{Mg}\left(\mathrm{NO}_{3}\right)_{2}$, $\mathrm{Ca}\left(\mathrm{NO}_{3}\right)_{2}$, and $\mathrm{Sr}\left(\mathrm{NO}_{3}\right)_{2}$, respectively; the alkaline-earth metals loading amount for each catalyst was $3 \mathrm{wt} \%$. The alkaline-earth metals modified ZSM- 5 type zeolites were first dried at $120{ }^{\circ} \mathrm{C}$ for $12 \mathrm{~h}$, followed by calcination at $550{ }^{\circ} \mathrm{C}$ for another $5 \mathrm{~h}$. The obtained catalysts were denoted as $\mathrm{Z}-\mathrm{M}-\mathrm{Mg}$, Z-M-Ca, and Z-M-Sr (Table 7).

\subsection{Catalyst Evaluation for n-Decane Catalytic Hydrocracking}

The catalytic cracking of the $n$-decane $\left(\mathrm{C}_{10} \mathrm{H}_{22}\right)$ reaction was carried out in a flowing fixed-bed reactor at different temperatures under a reaction pressure of $0.1 \mathrm{MPa}$. In brief, a $0.3 \mathrm{~g}$ catalyst was loaded in the center of the stainless-steel reactor in a flow of pure $\mathrm{H}_{2}(20 \mathrm{~mL} / \mathrm{min})$. The cracking reaction was implemented using $\mathrm{n}$-decane with $0.03 \mathrm{~mL} / \mathrm{min}$. The products were analyzed online via gas chromatographs (GC Sciences 390B, FID, Japan).

\subsection{Reaction Result Calculation Methods}

3.3.1. Conversion Calculation

$$
\mathrm{C}_{\mathrm{n} \text {-decane }}=\left(\mathrm{X}_{\mathrm{n} \text {-decane, in }}-\mathrm{X}_{\mathrm{m} \text {-decane, out }}\right) /\left(\mathrm{X}_{\mathrm{n} \text {-decane, in }}\right) \times 100
$$

$\mathrm{C}_{\mathrm{n} \text {-decane }}$ - Conversion of n-decane, \%;

$\mathrm{X}_{\mathrm{n} \text {-decane, in }}-$ Mole fraction of $\mathrm{n}$-decane in pristine reactant;

$\mathrm{X}_{\mathrm{n} \text {-decane, out }}-$ Mole fraction of $\mathrm{n}$-decane in exit gas.

3.3.2. Products Selectivity Calculation

$$
S_{i}=\frac{R_{i, s} f_{i, m}}{\sum_{i} R_{i, s} f_{i, m}}
$$

$\mathrm{S}_{\mathrm{i}}$-Mass selectivity of component $\mathrm{i}, \%$;

$\mathrm{R}_{\mathrm{i}, \mathrm{s}}$ - Area ratio of hydrocarbons in chromatogram;

$\mathrm{f}_{\mathrm{i}, \mathrm{m}}$-Correction of mass.

\subsection{Catalysts Characterization}

\subsubsection{XRD Analysis}

The crystalline structure of the sample was measured by X-ray diffraction (XRD) with a Rigaku RINT 2400 diffractometer employing $\mathrm{Cu} \mathrm{K} \alpha$ radiation. All samples were scanned at $40 \mathrm{kV}$ and $40 \mathrm{~mA}$ in the range of $5-80^{\circ}$.

\subsection{2. $\mathrm{NH}_{3}$-TPD Analysis}

The acidity of the catalysts was studied through temperature programmed desorption (TPD), using BELCAT-B-TT (BEL.JAPAN.INC., Japan) with $\mathrm{NH}_{3}$. The TPD of $\mathrm{NH}_{3}$ was carried out between 50 and $800{ }^{\circ} \mathrm{C}$ under a helium flow $(30 \mathrm{~mL} / \mathrm{min})$ with a heating rate of $10^{\circ} \mathrm{C} / \mathrm{min}$. Before the test, the samples were pretreated under helium atmosphere at $500{ }^{\circ} \mathrm{C}$ for $1 \mathrm{~h}$ and were then cooled to $50^{\circ} \mathrm{C}$ and exposed to pure $\mathrm{NH}_{3}(30 \mathrm{~mL} / \mathrm{min})$ for $0.5 \mathrm{~h}$. 


\subsubsection{Catalysts Texture Characterization}

Nitrogen adsorption measurements were carried out with an AUTOSORB-1 (Quantachrome Instruments, Japan), and the BET surface area and pore size distribution were determined from the isotherms. The samples were outgassed at $200{ }^{\circ} \mathrm{C}$ for $2 \mathrm{~h}$ before each test.

\subsubsection{TEM}

The microstructures of the zeolite samples were characterized with transmission electron microscopy (TEM, JEOL JEM-200CX working at $160 \mathrm{kV}$; JEOL JEM 2010F operated at $200 \mathrm{kV}$, Japan).

\subsubsection{SEM}

After coating a platinum layer on their surface (JEOL, JFC-1600, Japan), the morphology information of the catalysts was collected by Scanning Electron Microscope (SEM, JEOL JSM-6360 LV, Japan).

\subsubsection{EDX}

An energy dispersive X-ray spectrometer (EDX) was also employed to analyze the catalysts' element composition with an EDX-700 (SHIMADZU, Japan).

\section{Conclusions}

In this research, the mesoporous ZSM- 5 zeolite and metallic modified catalysts have been designed and studied in the n-decane hydrocracking reaction. Zeolite ZSM- 5 shows a good catalytic performance in the hydrocracking of n-decane. It also has a good stability and activity at a high temperature. With the increase of the $\mathrm{Si} / \mathrm{Al}$ molar ratio, the total acid sites of the ZSM-5 zeolite may decrease. The ability for hydrogenation and hydrocracking decreases.

Through the acid and alkali leaching of the zeolite, the mesopores and mesoporous channel are generated in the Z-100-M catalyst. The n-decane can easily access the acid sites of the zeolite through mesopores, and the hydrocracking process is also accelerated due to the exposed extra active sites. In addition, the acidity of the catalyst is weakened by the removal of Si and Al from the ZSM-5 zeolite, which leads to the products distribution drifting into more valuable olefin products.

To further optimize the products distribution in the n-decane hydrocracking reaction, several metallic promoters were used to modify the mesoporous ZSM- 5 zeolite. The process of catalytic hydrocracking becomes more thorough over the noble metal Pd-modified mesoporous ZSM- 5 zeolite catalyst. It exhibits an outstanding n-decane conversion and propane selectivity in the hydrocracking reaction due to the occurrence of a hydrogen spillover via the Pd promoter. The phenomenon of hydrogen spillover supplies more active sites for hydrocracking and hydrogenating in this reaction. In the alkaline-earth metal-modified catalysts, it exhibits a good catalytic performance for producing olefins in the hydrocracking of the n-decane reaction. With the alkalinity of the catalyst increasing, more olefins are formed because a moderate alkalinity limits the effective hydrogenation of the formed olefins into alkanes.

In a word, this study explores the important effect factors in n-decane hydrocracking reaction activity and products distribution, extending the horizontality of the design of mesoporous catalysts. In addition, it also shows a potential for further industrial applications according to the optimized products distribution under the metallic promoted mesoporous zeolite.

Author Contributions: The idea was conceived by N.T. and L.T.; L.T. performed the experiments and drafted the paper under the supervision of N.T.; X.G.(Xinhua Gao) and X.G. (Xiaoyu Guo) helped to collect and analyse some characterization data. The manuscript was revised and checked through the comments of all authors. All authors have given approval for the final version of the manuscript.

Funding: This research was supported by the Foundation of State Key Laboratory of High-Efficiency Utilization of Coal and Green Chemical Engineering (Grant No. 2019-KF-23).

Conflicts of Interest: The authors declare no conflict of interest. 


\section{References}

1. Welters, W.J.J.; Van Der Waerden, O.H.; De Beer, V.H.J.; Van Santen, R.A. Hydrocracking of n-Decane over Zeolite-Supported Metal Sulfide Catalysts. 2. Zeolite Y-Supported Ni and Ni-Mo Sulfides. Ind. Eng. Chem. Res. 1995, 34, 1166-1171. [CrossRef]

2. Bachmann, R.T.; Johnson, A.C.; Edyvean, R.G. Biotechnology in the petroleum industry: An overview. Int. Biodeterior. Biodegradation 2014, 86, 225-237. [CrossRef]

3. Li, J.; Wu, L.; Yang, Z. Analysis and upgrading of bio-petroleum from biomass by direct deoxy-liquefaction. J. Anal. Appl. Pyrolysis 2008, 81, 199-204. [CrossRef]

4. Bricker, M.; Thakkar, V.; Petri, J. Hydrocracking in Petroleum Processing. In Handbook of Petroleum Processing; Treese, S., Jones, D., Pujado, P., Eds.; Springer: Cham, Switzerland, 2014; pp. 1-35.

5. Tan, L.; Erdenebaatar, O.; Liu, G.; Yamane, N.; Ai, P.; Otani, A.; Yoneyama, Y.; Yang, G.; Tsubaki, N. Catalytic cracking of 4-(1-naphthylmethyl)bibenzyl in sub- and supercritical water. Fuel Process. Technol. 2017, 160, 34-38. [CrossRef]

6. Su, J.; Zhou, H.; Liu, S.; Wang, C.; Jiao, W.; Wang, Y.; Liu, C.; Ye, Y.; Zhang, L.; Zhao, Y.; et al. Syngas to light olefins conversion with high olefin/paraffin ratio using $\mathrm{ZnCrOx} / \mathrm{AlPO}-18$ bifunctional catalysts. Nat. Commun. 2019, 10, 1297. [CrossRef] [PubMed]

7. Jiao, F.; Pan, X.; Gong, K.; Chen, Y.; Li, G.; Bao, X. Shape-Selective Zeolites Promote Ethylene Formation from Syngas via a Ketene Intermediate. Angew. Chem. 2018, 130, 4782-4786. [CrossRef]

8. Claeys, M. Cobalt gets in shape. Nature 2016, 538, 44-45. [CrossRef] [PubMed]

9. de Jong, K.P. Suprised by selectivity. Science 2016, 351, 1030-1031. [CrossRef]

10. Jiao, F.; Pan, X.; Xiao, J.; Li, H.; Ma, H.; Wei, M.; Pan, Y.; Zhou, Z.; Li, M.; Miao, S.; et al. Selective conversion of syngas to light olefins. Science 2016, 351, 1065-1068. [CrossRef]

11. Cheng, K.; Gu, B.; Liu, X.; Kang, J.; Zhang, Q.; Wang, Y. Direct and Highly Selective Conversion of Synthesis Gas into Lower Olefins: Design of a Bifunctional Catalyst Combining Methanol Synthesis and Carbon-Carbon Coupling. Angew. Chem. Int. Ed. 2016, 55, 4725-4728. [CrossRef]

12. Welters, W.J.J.; Van Der Waerden, O.H.; Zandbergen, H.W.; De Beer, V.H.J.; Van Santen, R.A. Hydrocracking of N-Decane over Zeolite-Supported Metal Sulfide Catalysts. 1. CaY-Supported Transition Metal Sulfides. Ind. Eng. Chem. Res. 1995, 34, 1156-1165. [CrossRef]

13. Liang, J.; Liang, Z.; Zou, R.; Zhao, Y. Heterogeneous Catalysis in Zeolites, Mesoporous Silica, and Metal-Organic Frameworks. Adv. Mater. 2017, 29, 1701139. [CrossRef] [PubMed]

14. Weckhuysen, B.M.; Yu, J. Recent advances in zeolite chemistry and catalysis. Chem. Soc. Rev. 2015, 44, 7022-7024. [CrossRef] [PubMed]

15. Na, K.; Somorjai, G.A. Hierarchically Nanoporous Zeolites and Their Heterogeneous Catalysis: Current Status and Future Perspectives. Catal. Lett. 2014, 145, 193-213. [CrossRef]

16. Turkevich, J. Zeolites as Catalysts. I. Catal. Rev. 1968, 1, 1-35. [CrossRef]

17. Weitkamp, J. Zeolites and catalysis. Solid State Ionics 2000, 131, 175-188. [CrossRef]

18. Tian, Y.; Zhang, B.; Liang, H.; Hou, X.; Wang, L.; Zhang, X.; Liu, G. Synthesis and performance of pillared HZSM-5 nanosheet zeolites for n-decane catalytic cracking to produce light olefins. Appl. Catal. A Gen. 2019, 572, 24-33. [CrossRef]

19. Meng, L.; Zhu, X.; Hensen, E.J.M. Stable Fe/ZSM-5 Nanosheet Zeolite Catalysts for the Oxidation of Benzene to Phenol. ACS Catal. 2017, 7, 2709-2719. [CrossRef]

20. Losch, P.; Pinar, A.B.; Willinger, M.G.; Soukup, K.; Chavan, S.; Vincent, B.; Pale, P.; Louis, B. H-ZSM-5 zeolite model crystals: Structure-diffusion-activity relationship in methanol-to-olefins catalysis. J. Catal. 2017, 345, 11-23. [CrossRef]

21. Verheyen, E.; Jo, C.; Kurttepeli, M.; Vanbutsele, G.; Gobechiya, E.; Koranyi, T.I.; Bals, S.; Van Tendeloo, G.; Ryoo, R.; Kirschhock, C.E.; et al. Molecular shape-selectivity of MFI zeolite nanosheets in n-decane isomerization and hydrocracking. J. Catal. 2013, 300, 70-80. [CrossRef]

22. Inagaki, S.; Shinoda, S.; Kaneko, Y.; Takechi, K.; Komatsu, R.; Tsuboi, Y.; Yamazaki, H.; Kondo, J.N.; Kubota, Y. Facile Fabrication of ZSM-5 Zeolite Catalyst with High Durability to Coke Formation during Catalytic Cracking of Paraffins. ACS Catal. 2012, 3, 74-78. [CrossRef]

23. Louis, B.; Reuse, P.; Kiwi-Minsker, L.; Renken, A. Synthesis of ZSM-5 coatings on stainless steel grids and their catalytic performance for partial oxidation of benzene by N2O. Appl. Catal. A Gen. 2001, 210, 103-109. [CrossRef] 
24. Roussel, M. Mechanisms of $\mathrm{n}$-decane hydrocracking on a sulfided NiW on silica-alumina catalyst. J. Catal. 2003, 218, 427-437. [CrossRef]

25. Mirodatos, C.; Barthomeuf, D. Cracking of n-decane on zeolite catalysts: Enhancement of light hydrocarbon formation by the zeolite field gradient. J. Catal. 1988, 114, 121-135. [CrossRef]

26. Liu, J.; Jiang, G.; Liu, Y.; Di, J.; Wang, Y.; Zhao, Z.; Sun, Q.; Xu, C.; Gao, J.; Duan, A.; et al. Hierarchical Macro-meso-microporous ZSM-5 Zeolite Hollow Fibers with Highly Efficient Catalytic Cracking Capability. Sci. Rep. 2014, 4, 7276. [CrossRef] [PubMed]

27. Verboekend, D.; Pérez-Ramírez, J. Design of hierarchical zeolite catalysts by desilication. Catal. Sci. Technol. 2011, 1, 879. [CrossRef]

28. De Jong, K.P.; Zečević, J.; Friedrich, H.; De Jongh, P.E.; Bulut, M.; Van Donk, S.; Kenmogne, R.; Finiels, A.; Hulea, V.; Fajula, F. Zeolite Y Crystals with Trimodal Porosity as Ideal Hydrocracking Catalysts. Angew. Chem. 2010, 122, 10272-10276. [CrossRef]

29. Pérez-Ramírez, J.; Christensen, C.H.; Egeblad, K.; Christensen, C.H.; Groen, J.C. Hierarchical zeolites: Enhanced utilisation of microporous crystals in catalysis by advances in materials design. Chem. Soc. Rev. 2008, 37, 2530. [CrossRef] [PubMed]

30. Groen, J.C.; Moulijn, J.A.; Pérez-Ramírez, J. Desilication: On the controlled generation of mesoporosity in MFI zeolites. J. Mater. Chem. 2006, 16, 2121-2131. [CrossRef]

31. Groen, J.C.; Peffer, L.A.A.; Moulijn, J.A.; Pérez-Ramírez, J.; Pérez-Ramírez, J. Mechanism of Hierarchical Porosity Development in MFI Zeolites by Desilication: The Role of Aluminium as a Pore-Directing Agent. Chem. A Eur. J. 2005, 11, 4983-4994. [CrossRef]

32. Biffis, A.; Centomo, P.; del Zotto, A.; Zecca, M. Pd Metal Catalysts for Cross-Couplings and Related Reactions in the 21st Century: A Critical Review. Chem. Rev. 2018, 118, 2249-2295. [CrossRef] [PubMed]

33. Hill, M.S.; Liptrot, D.J.; Weetman, C. Alkaline earths as main group reagents in molecular catalysis. Chem. Soc. Rev. 2016, 45, 972-988. [CrossRef] [PubMed]

34. Tan, L.; Yang, G.; Yoneyama, Y.; Kou, Y.; Tan, Y.; Vitidsant, T.; Tsubaki, N. Iso-butanol direct synthesis from syngas over the alkali metals modified Cr/ZnO catalysts. Appl. Catal. A Gen. 2015, 505, 141-149. [CrossRef]

35. Surry, D.S.; Buchwald, S.L. Dialkylbiaryl Phosphines in Pd-Catalyzed Amination: A User's Guide. Chem. Sci. 2011, 2, 27-50. [CrossRef] [PubMed]

36. Xue, L.; He, H.; Liu, C.; Zhang, C.; Zhang, B. Promotion effects and mechanism of alkali metals and alkaline earth metals on cobalt-cerium composite oxide catalysts for N2O decomposition. Environ. Sci. Technol. 2009, 43, 890-895. [CrossRef] [PubMed]

37. Ciuparu, D.; Lyubovsky, M.R.; Altman, E.; Pfefferle, L.D.; Datye, A. Catalytic combustion of methane over palladium-based catalysts. Catal. Rev. 2002, 44, 593-649. [CrossRef]

38. Yoo, K.S.; Yoon, C.H.; Jung, K.W. Oxidative Palladium(II) Catalysis: A Highly Efficient and Chemoselective Cross-Coupling Method for Carbon-Carbon Bond Formation under Base-Free and Nitrogenous-Ligand Conditions. J. Am. Chem. Soc. 2006, 128, 16384-16393. [CrossRef] [PubMed]

39. Kobayashi, S.; Yamashita, Y. Alkaline Earth Metal Catalysts for Asymmetric Reactions. Acc. Chem. Res. 2011, 44, 58-71. [CrossRef] [PubMed]

40. Karim, W.; Spreafico, C.; Kleibert, A.; Gobrecht, J.; Vandevondele, J.; Ekinci, Y.; Van Bokhoven, J.A. Catalyst support effects on hydrogen spillover. Nature 2017, 541, 68-71. [CrossRef]

41. Adams, B.D.; Ostrom, C.K.; Chen, S.; Chen, A. High-Performance Pd-Based Hydrogen Spillover Catalysts for Hydrogen Storage. J. Phys. Chem. C 2010, 114, 19875-19882. [CrossRef]

42. Contescu, C.I.; Brown, C.M.; Liu, Y.; Bhat, V.V.; Gallego, N.C. Detection of Hydrogen Spillover in Palladium-Modified Activated Carbon Fibers during Hydrogen Adsorption. J. Phys. Chem. C 2009, 113, 5886-5890. [CrossRef]

43. Li, Y.; Yang, R.T. Hydrogen Storage in Metal-Organic Frameworks by Bridged Hydrogen Spillover. J. Am. Chem. Soc. 2006, 128, 8136-8137. [CrossRef] [PubMed]

(C) 2019 by the authors. Licensee MDPI, Basel, Switzerland. This article is an open access article distributed under the terms and conditions of the Creative Commons Attribution (CC BY) license (http://creativecommons.org/licenses/by/4.0/). 